\title{
Modeling Lactation Curve in Primiparous Beef Cattle
}

\author{
Ana C. Espasandin ${ }^{1}$, Verónica Gutierrez ${ }^{2}$, Alberto Casal $^{3}$, Ana Graña ${ }^{4}$, Oscar Bentancur ${ }^{6} \&$ Mariana Carriquiry ${ }^{3}$ \\ ${ }^{1}$ Departament of Animal and Forage Sciences, School of Agronomy, EEMAC, Udelar-Universidad de la \\ República, Paysandú, Uruguay \\ ${ }^{2}$ Microsules Laboratory, Uruguay \\ ${ }^{3}$ Departament of Animal and Forage Sciences, School of Agronomy, Udelar-Universidad de la República, \\ Garzón, Uruguay \\ ${ }^{4}$ MGAP (Ministry of Livestock, Agriculture and Fisheries), Uruguay \\ ${ }^{5}$ Departament of Animal and Forage Sciences, School of Agronomy, EEBR, Udelar-Universidad de la República, \\ Cerro Largo, Uruguay \\ ${ }^{6}$ Departament of Biometrics, Statistics and Computation, Paysandú, Uruguay \\ Correspondence: Ana C. Espasandin, Departament of Animal and Forage Sciences, School of Agronomy,

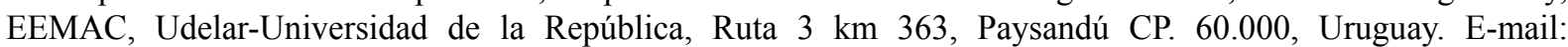 \\ acespasa@fagro.edu.uy
}

Received: January 31, 2016 Accepted: February 29, 2016 Online Published: March 15, 2016

doi:10.5539/jas.v8n4p116 URL: http://dx.doi.org/10.5539/jas.v8n4p116

\begin{abstract}
The work describes lactation curves and compares two methods to estimate milk yield (MY) in a grazing beef cattle herd of the EEBR Station-Udelar, Uruguay. Twenty-four Hereford, Angus and F1-crossbreed primiparous cows were used to estimate MY once a month, from birth to weaning, by weigh-suckle-weigh (WSW) technique and milking-machine (MM). Milk yield (MY), milk yield retained energy (ReMY), and calf weight were analyzed as repeated measures in a model including: sex of calves, month of lactation, cow and calf breed, milking method, estimation day ( 1 or 2), and post-partum days as fixed effects, and cow nested within breed as the random effect. The correlation analysis and the Gage $\mathrm{r} \& \mathrm{R}$ coefficient (repeatability and reproducibility) between the two methods were used to study their associations. Lactation curves were compared (AICC and BIC) using Wood (1964), and Jenkins and Ferrel (1984) models. The MY estimated differed with the methodology being WSW higher than MM $(\mathrm{P}<0.001)$. The $\mathrm{r} \& \mathrm{R}$ coefficient $(0.83)$ suggest lower associations between WSW and $\mathrm{MM}$, being $18 \%$ and $6 \%$ the coefficients of variation, respectively. Cow breed was not significant for MY. Calf live weight and ReMY were negatively associated $(-0.52, \mathrm{P}<0.0001)$. Based on variability observed, MM is more accurate to estimate MY and Wood curve the most adjusted to describe lactation in grazing beef cattle.
\end{abstract}

Keywords: beef cattle, lactation, milk yield, weight-suckle-weight

\section{Introduction}

Beef cattle are a primary structure in the beef industry and can be characterized by their body size, energetic requirements, reproductive performance, and milk production and composition (Fiss \& Wilton, 1989).

Milk production and composition of the cows is an important trait for growth and development of calves during the lactation period in beef cattle (Gaskins \& Anderson, 1980; Mondragón, Wilton, Allen, \& Song, 1983; Yokoi, Moriya, \& Sasaki, 1997). Milk production in beef cattle varies with the nutrition plan, and with dam and calves genotype.

The sex of the calf had influences in some cases (Day, Imakawa, Clutter, Wolfe, Zalesky, Nielsen, \& Kinder, 1987; Jenkins \& Ferrel, 1992) stimulating the males more milk production in dams. Also, milk production is an important trait related to maintenance requirements and efficiency of production in beef cattle (Montaño-Bermudez, Nielsen, \& Deustcher, 1990; Jenkins \& Ferrell, 1994).

The study of the lactation curves can contribute to understand the production systems and allow the prediction of the milk production in any state period. Several papers explain the importance of finding adequate lactation curves, since in many cases are used to determine genetic values for maintenance requirements (Strabel \& 
Misztal, 1999). Recent genetic values for maintenance requirements evaluated for the American Red Angus Association, use the lactation curves with adjusted model for dairy cattle (Evans, 2001). Many equations have been proposed to describe the curve of lactation in dairy cattle since it is mostly used for non-linear type (Wood, 1967). Alencar, Ruzza, and Porto (1995), and Espasandin and Alencar (2003) found that non-linear curves described in Jenkins and Ferrell (1984) result were more adjusted for Nellore and Canchim beef cattle. However, an important source of variation is the methodology to estimate the milk production of the cow (Dawson, Cook, \& Knapp, 1960). Two methods for milk yield estimation are the most frequently used: the weigh-suckle-weigh (Williams, Anderson, \& Kress, 1979) and the Machine Milking with previous injection of oxitocine (Quintans, Banchero, Carriquiry, López-Mazz, \& Baldi, 2010). Espasandin, Packer, and Alencar (2001) reported the imprecision of the weigh-suckle-weigh method due the weigh variations produced by calves' losses: urine, feces, as well as the suckling of a cow for more than one calves. Totusek, Arnett, Holland, and Whiteman (1973) comparing milk estimations from weighting calf or handling milking, founded lesser variability and higher estimations in weigh-suckle-weigh method. Based on previous studies, this work aimed to compare two methods (weigh-suckle-weigh and milking machine) to estimate milk yield, and describe the phenotypic curves of lactation in primiparous Hereford, Angus and F1-crosses cows using linear and non-linear models.

\section{Materials and Methods}

\subsection{Localization}

The study was conducted at the Bernardo Rosengurtt Experimental Station of Agronomy School (Udelar) in Cerro Largo, Uruguay (Latitude: $-32.3833^{\circ}$ and Longitude: $-54.35^{\circ}$ ) between October 2008 and March, 2009. Animal procedures were approved by the Animal Experimentation Committee of Universidad de la República (CHEA-Udelar, Uruguay).

\subsection{Determinations}

Milk production ( $\mathrm{kg} / \mathrm{day})$ was measured once a month during lactation period (6 month) in 24 cows (8 Hereford $(\mathrm{HH}), 8$ Angus (AA) and 8 F1 crosses primiparous cows. Estimations were made by weigh-suckle-weigh (WSW) method twice a day (7.00 am and $3.00 \mathrm{pm}$ ), and with portable milking machine (MM) once a day. Calving period of primiparous cows were given in the spring, from September to November. F1 cows breed backcross calves (AA and $\mathrm{HH}$ ) and pure breed cows (HH and $\mathrm{AA}$ ) had both, pure breed or F1 crossbreed calves.

The cows were divided in two groups; the first group was measured by WSW in day 1, while the second group was measured by MM, in the first month of lactation. In the second and subsequent measures of milk production, the order of groups was inverted successively. The WSW method as described by Williams et al. (1979) consists to weigh the calves before and after suckling their dams (to satiety) after previously separated for six hours. The difference between pre- and post-suckling weights was recorded as estimated milk production (daily) of the dam. During the suckling period (approximately 10-15 minutes) fecal and urine losses were observed (some recorded) and corrected in the calves' weight assuming similar weight of each loss (urine or feaces). The interval from calf separation to nursing for WSW was recorded. In MM, cows were milked in the morning (to emptier the udder) and in the afternoon, receiving each cow $20 \mathrm{IU}$ of oxytocin immediately prior to the application of a milking machine. The milking machine was removed when milk flow from udder ceased. Milk was weighted in the afternoon collection and the time interval from calf separation to milking was recorded. A sample of milk was collected to analyze fat, non-fat solids, protein and lactose.

Along the experimental period, the animals grazed a native pastures (Pallares, Berretta, \& Maraschin, 2005), at the allowances of $1400 \mathrm{Kg} \mathrm{DM} / \mathrm{ha}$, and 7.3\% CP, 41.5\% ADF, 72.4\% NDF and 9\% ashes. Ash content and CP were determined according to AOAC (Official Method 942.05 and 984.13, 2012, respectively). NDF and ADF were measured with an ANKOM 220 Fiber Analyzer (Ankom Technology Corporation, Fairport, NY). Analyses were performed in the Nutrition Laboratory of School of Agronomy, Udelar.

Retained Metabolizable Energy on milk (ReMY, Mcal/day) was estimated using the equation proposed by Tyrrell $\&$ Reid (1965), where:

$$
\operatorname{ReMY}=\{[(0.057 \times \% \mathrm{P})+(0.092 \times \% \mathrm{~F})+(0.0395 \times \% \mathrm{~L})] \times \mathrm{kg} \mathrm{MY} / \mathrm{day}\}
$$

Where, $\mathrm{P}=$ Protein, $\mathrm{L}=$ Lactose, and $\mathrm{F}=$ Fat.

\subsection{Statistical Analysis}

Milk estimations by two methods (WSW and MM) were extrapolated to $24 \mathrm{~h}$ (milk produced/day assuming a linear trend in milk production) and analyzed with a repeated measures. The model including the fixed effects of method (MM and WSW), sex of calves, month of lactation, day of measure (1 or 2), cow breed, calf breed nested 
on dam breed; post-partum days as a covariate, and the random effect of the cow. Statistical significances of effects were assumed when $\mathrm{P}<0.05$, and trends were considered when $0.05<\mathrm{P} \leq 0.1$.

The variability between WSW and MM methods were studied using the Gage r\&R method. This method analyzes the variability using the ANOVA (Arbelaez et al., 2007). The repeatability (r) and Reproducibility (R) are estimated using the variance components ratios (Barrentine, 1991; Arbelaez et al., 2007). The r\&R coefficient is the square root of the variance between animals (operators in Gage r\&R studies), method and interaction, respectively $\left(r \& R=\sqrt{r^{2}+R^{2}+I^{2}}\right)$. If the $r \& R$ coefficient is lower than $10 \%$, the compared methods can be considered as similar, if $10 \% \leq \mathrm{r} \& \mathrm{R} \leq 30$ the methodologies can be accepted but in some cases, but if the value is higher than $30 \%$ the methods are considered as different.

Relationships between calf weight and milk yield (WSW and MM) were studied by regression and correlation analysis. Linear, quadratic and cubic regression models were used to shape the lactation curves, including or not the random animal (cow) effect. Estimated milk production by MM method corrected for fixed effects was regressed on week of lactation (t), using non-linear models published by Jenkins and Ferrel (1984) (JF) and Wood (1964) (W). In the JF curve $y_{n}=n / a^{k n}$, the $y_{n}$ is the milk production in week $n$, and $a$ and $k$ are the parameters of the curve definition. In the $\mathrm{W}$ curve, the model $y_{t}=a t^{b} e^{-c t}$ describes the milk production $(y)$ as a function of time $(t)$; and $a$ (production level), $b$ (rate increasing milk yield), and $c$ (decline rate after peak) are the parameters of the incomplete gamma function. The milk production in each week was obtained for each cow. The significance of the genetic group of the cows were considered by means the inclusion of different coefficients ( $\mathrm{a}, \mathrm{b}$ and $\mathrm{c}$ ) in $\mathrm{W}$ and J\&F models. Analyses were performed using NLMIXED procedure (SAS, 2009). AICC (Adjusted Akaike's Information Criterion) and BIC (Bayesian Information Criterion) criteria's were used to compare both models (JF and W). The values of parameters of shaped curve were used to estimate time and milk yield at peak. Values were analyzed (ANOVA) and compared genetic groups. The estimated values of coefficients $\mathrm{a}, \mathrm{b}$ and $\mathrm{c}$ and the random cow effect allowed to estimate the milk yield at peak $\left(a(b / c)^{b} e^{-b}\right)$, as well the days at peak $(b /(c \times 7))$.

ReMY and calf live weight were studied by correlation analysis using the CORR procedure (SAS, 2009).

\section{Results}

Cow breed and calf breed nested on dam, sex of calf, and post-partum days had no significance $(P>0.05)$ in milk yield. However, themethodology to estimate milk production, the day of measure and the month of lactation had high significance $(\mathrm{P}<0.01)$, as showed in Table 1 .

Table 1. Influence of fixed effects and covariate in milk production estimations (ANOVA)

\begin{tabular}{ll}
\hline Effect & Statistical Signifficance (Pr $>$ F) \\
\hline Method of estimation (WSW and PMP) & 0.0005 \\
Cow Breed & 0.3776 \\
Calf breed nested on dam breed & 0.5570 \\
Sex of calf & 0.3575 \\
Day of estimation (first or second) & 0.0003 \\
Post-partum days & 0.8436 \\
\hline
\end{tabular}

Figure 1 show the milk production ( $\mathrm{kg} / \mathrm{cow}$-day) obtained by both WSW and MM methods along the lactation period. 


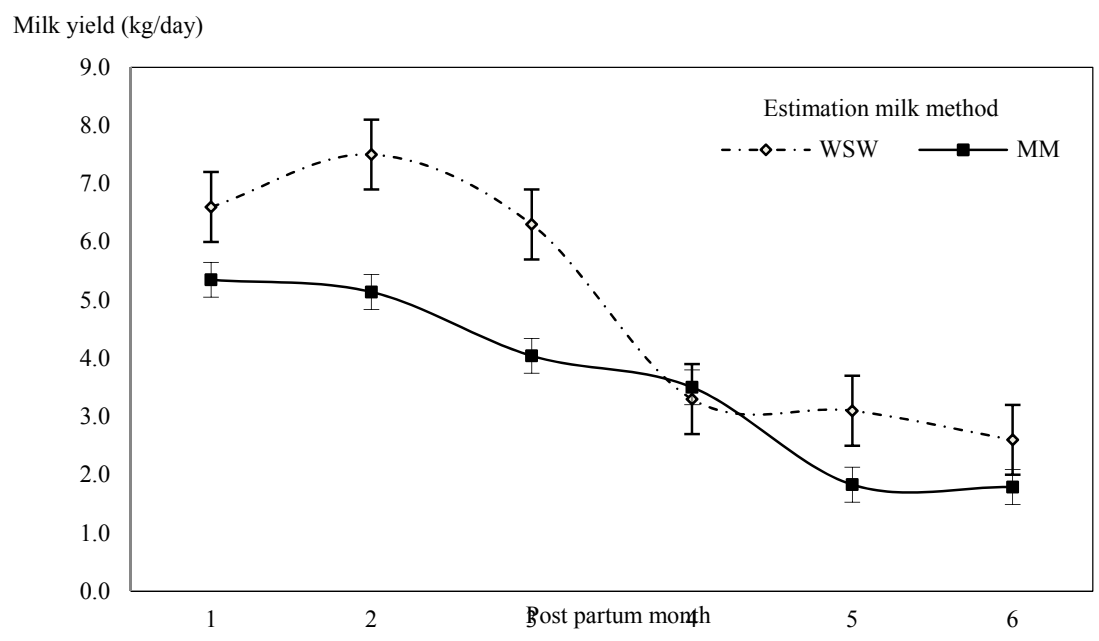

Figure 1. Milk yield estimation in primiparous beef cattle by two methods (MM and WSW) along lactation period (post partum month)

The milk production over the lactation period differed with the methodologies of estimation $(\mathrm{P}<0.001)$. WSW showed higher values in milk production than MM estimation, except in the $4^{\text {th }}$ month of lactation where no differences were observed. The range in $\mathrm{r} \& \mathrm{R}$ coefficients was $83 \%(\mathrm{r}=72 \%$ and $\mathrm{R}=41 \%)$, suggesting a low repeatability and reproducibility between both methods. As the $\mathrm{r} \& \mathrm{R}$ criteria proposed, values above $30 \%$ mean that both methods should be considered as different.

The standard errors (SE) observed in milk production, showed different variation associated with the estimation methodology of milk production. In WSW, the SE were 0.62, 0.64, 0.60, 0.58, 0.62 and 0.59 for milk produced in month $1^{\circ}$ to $6^{\text {th }}$, respectively; while in MM, the SE were $0.29,0.30,0.29,0.28,0.29$ and 0.28 , respectively. In Both MM and WSW, the coefficient of variation of the mean increases with declining in milk production along lactation period, from $5.4 \%$ to $15.6 \%$ in $\mathrm{MM}$ and from $9.4 \%$ to $22.7 \%$ in WSW, respectively (Table 2).

Table 2. Coefficient of Variation (CV) observed in milk production estimated by WSW and MM methods in primiparousbeef cattle

\begin{tabular}{llc}
\hline \multirow{2}{*}{ Month of Lactation } & \multicolumn{3}{c}{$\begin{array}{c}\text { CV (\%) inWSW and MM methodologies to } \\
\text { estimate milk production in beef cattle }\end{array}$} \\
\cline { 2 - 3 } & WSW & MM \\
\hline 1 & 9.4 & 5.4 \\
2 & 8.5 & 5.8 \\
3 & 9.5 & 7.2 \\
4 & 17.6 & 7.9 \\
5 & 20.0 & 15.8 \\
6 & 22.7 & 15.6 \\
\hline
\end{tabular}

When linear models (linear, quadratic and cubic models) where adjusted, the cubic model had the most adjustment $\left(r^{2}=0.96-0.99\right)$. However, when random effect was included, the linear models decline the adjustment $\left(r^{2}=0.49-0.56\right)$, being non-linear model the most appropriated to describe the lactation curves in these cows.

In this dataset, the non-linear models published by Jenkins and Ferrel (1984) and Wood (1967) showed different adjustments, being that the AICC and BIC criteria were lower (396 and 411, respectively) in Wood than in J\&F curves ( 425 and 436, respectively). Figure 2 show the most adjusted curve (Wood) observed in this beef herd. 


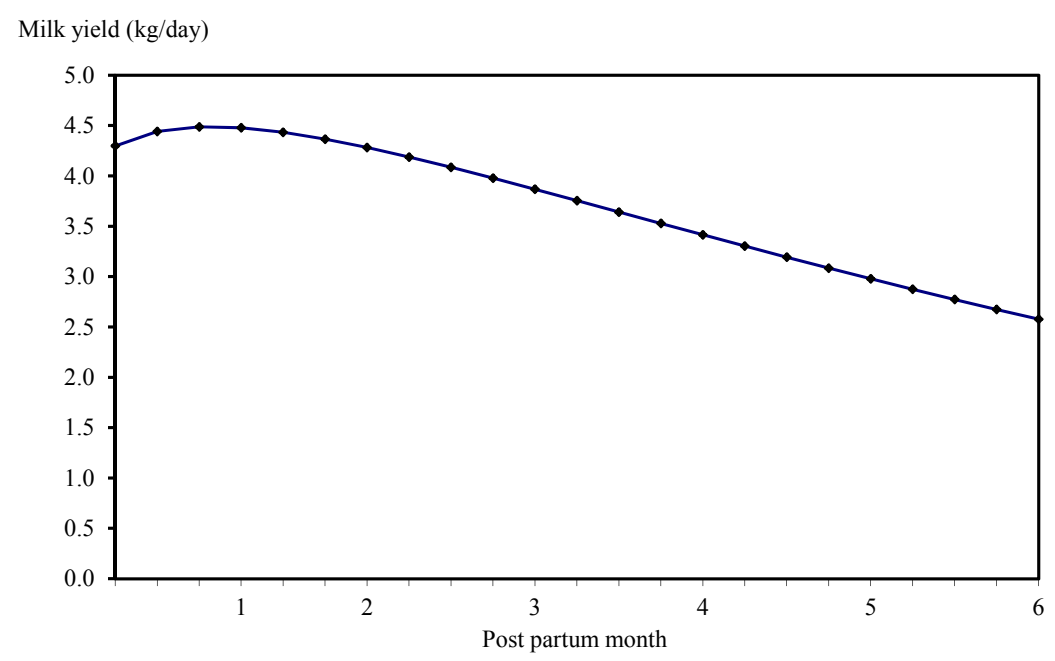

Figure 2. Lactation curve adjusted by Wood model (1967) in primiparous beef cows grazing native pastures of Uruguay

The inclusion of the different coefficients ( $a, b$ and $c$ ) for each genetic group did not improve the adjustment coefficients in the general curves (all genetic groups) ( $\mathrm{r}^{2}$, AICC and BIC), suggesting the no significance of breed effect. Nevertheless, in spite of observed higher adjustments, the wood curve was the best model to describe the lactation of grazing beef heifers $\left(r^{2}=0.88\right.$ and lower AICC and BIC criteria). Meanwhile, the J\&F model reached an intermediate determination coefficient $\left(\mathrm{r}^{2}=0.81\right)$. The estimated values of coefficients were a $=5.4 \pm 0.27, \mathrm{~b}=0.19 \pm 0.13$ and $\mathrm{c}=0.18 \pm 0.05$, and the random cow effect $=0.43 \pm 0.05$. The milk production at peak was $5.2 \mathrm{~kg} /$ day being reached at 33.9 post-partum days.

The retained energy on milk yield ReMY varied significantly with the month of lactation $(\mathrm{P}<0.0001)$, and cow's breed showed a statistical trend $(\mathrm{P}=0.06)$. The ReMY per day is shown in Figure 3.

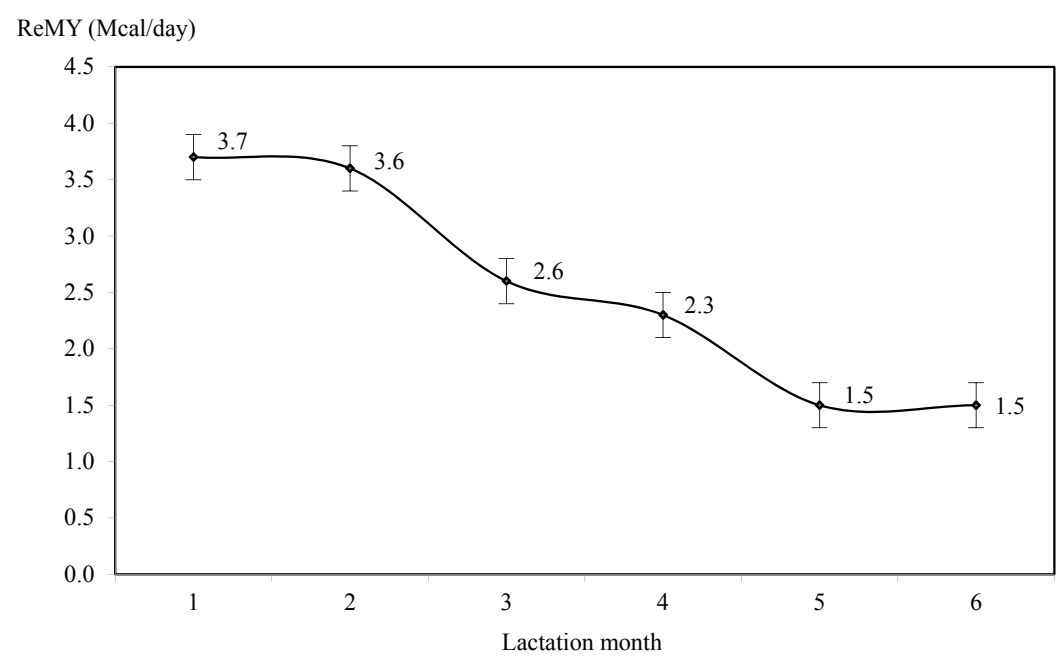

Figure 3. Retained Milk Yield (ReMY) along lactation period in primiparous beef cows grazing native pastures of Uruguay

The ReMY/day showed higher values in the first two months of the lactation (3.7 and 3.6 $\pm 0.2 \mathrm{Mcal} / \mathrm{day})$ and is reduced over the lactation period $(1.5 \pm 0.2 \mathrm{Mcal} /$ day in the last month of lactation). The calf live weight varied 
inversely and correlated negatively $(r=-0.52)$ with the ReMY. The solid components on milk showed higher percentages in protein and fat at the beginning $(2.9 \pm 0.2 \%$ and $3.9 \pm 0.5 \%$, respectively) and the end of lactation $(4.4 \pm 0.2 \%$ and $5.4 \pm 0.5 \%$, respectively) and decrease in Lactose percentage along lactation period (from $5.3 \pm 0.1 \%$ to $4.6 \pm 0.1 \%$, respectively).

Significant differences at the end of lactation period $(\mathrm{P}<0.01)$ were observed in the live weight of calves weaned by different dams breed, being F1 dams who weaned heavier calves (Figure 4).

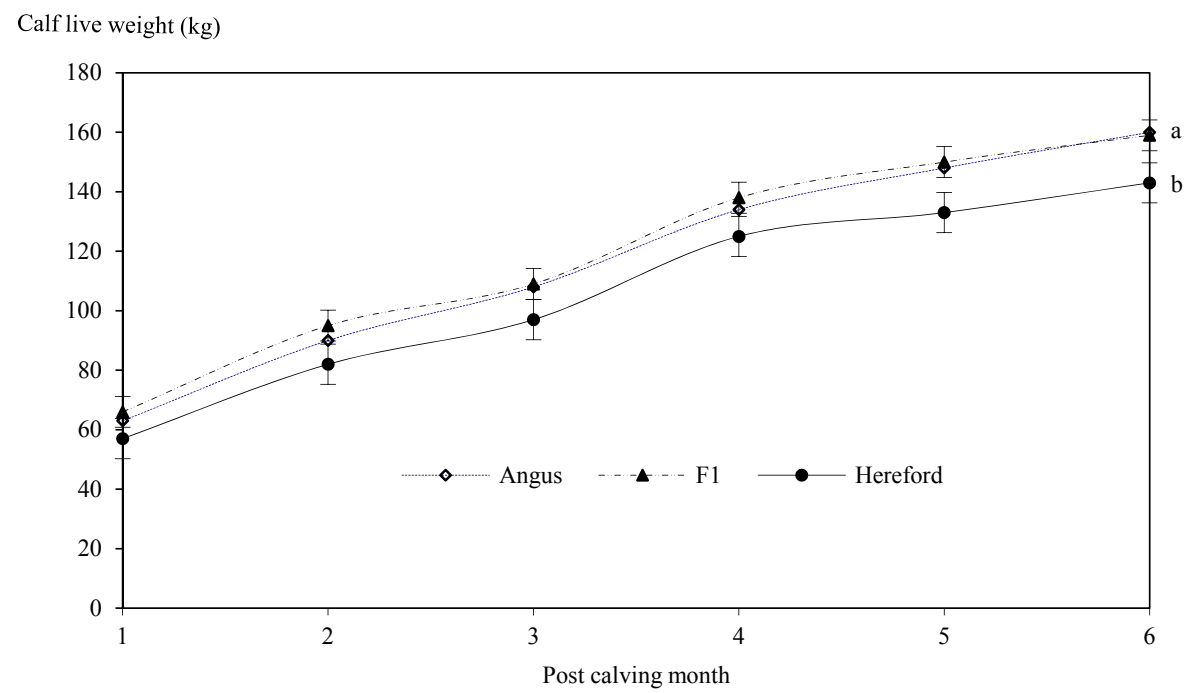

Figure 4. Live weight evolution $(\mathrm{Kg})$ along lactation period of calves nursed by primiparous $\mathrm{HH}, \mathrm{AA}$ and F1 dams grazing native pastures of Uruguay

As shown in the graphic, in the beginning of the lactation (1 month), all genotypes had similar weight $(61.7 \pm 4.9$ $\mathrm{kg})$. From the $4^{\text {th }}$ to $5^{\text {th }}$ months, a trend $(\mathrm{P}=0.1$ and $\mathrm{P}=0.08$, respectively) was observed between calves from $\mathrm{HH}$ and F1 dams. Calves of $\mathrm{HH}$ dams $(121.3 \pm 6.5 \mathrm{~kg})$ tended to be lighter than calves from $\mathrm{F} 1 \mathrm{cows}(138.2 \pm 4.9$ $\mathrm{kg}$ ) but both did not differ significantly with AA cow's calves (134.2 \pm 5.7$)$. At weaning, both, F1 and AA calves were significantly heavier than $\mathrm{HH}$ dams $(\mathrm{P}=0.0001)$, with $159.2 \pm 5.1 \mathrm{~kg}$ and $139.2 \pm 5.1 \mathrm{~kg}$, respectively.

Although, the correlation coefficients between fitted (Wood) and originals (WSW and MM) milk productions, and live weight of the calves were moderate and significant $(\mathrm{r}=-0.68$ and -0.46 , respectively, $\mathrm{P}<0.0001)$. However, the inclusion of milk yield (fitted (W) and original WSW and MM) as a covariate in the model to analyze calves weight over the lactation period, was not significant $(\mathrm{P}>0.05)$. Probably, a non-linear model is more appropriate to describe this relationship.

Additionally, the correlation coefficients between the milk production and the calves live weight varied with the milking method. Milk production obtained by MM was more strongly related to live weight $(r=-0.56)$ than WSW milk method $(r=-0.36)$. Probably, these differences are explained by the previously mentioned errors in WSW method.

\section{Discussion}

The estimated milk yield in this experiment varied with the applied methodology (WSW or MM). Along the lactation period, both, WSW and MM methods differed in MY estimations each month with the exception of the $4^{\text {th }}$ post- partum month, when milk yield were similar (3.3 and $3.5 \mathrm{~kg} /$ day, respectively). Based on observed MY evolution (Figure 1), probably some errors occurred in WSW method, as urine or faecal not observed losses. The r\&R coefficients value was $83 \%$ (with $r=72 \%$ and $R=41 \%$ ), suggesting low correlation coefficients between MM and WSW methods. As indicated by Arbelaez et al. (2007), values of r\&R coefficients higher than 30\% indicate that measures (methods) are not similar and should be considered as different. Probably, the MM measures are closer than the potential dam capacity to produce milk in a delimited period, as well as the WSW method is more related to the calf capacity to suckle. Ünal et al. (2007) indicated that the WSW method estimate less milk yield than manual milking after injection of oxytocin. Jenkins and Ferrell (1984) suggested that WSW is an appropriate method to estimate milk consumption of calve, but not accurate to estimate the real milk 
production of the dams. Milk consumption of calf depends of the dam production, and the suckling behavior of the calf. Also, as reported by Alencar, Cruz, Tullio, and Corrêa (1995) and Jenkins and Ferrel (1992) the number of suckles is influenced by sex, age and breed of calves. However, if the MY estimated by WSW method is correlated with milk suckled by calves, the values observed should be lower than or equal than to those obtained by MM. The values observed in this experiment showed opposite trends, beingmilk estimation in MM lower than in WSW. These results are in agreement with Jenkins, Ferrel, and Cundiff (1986), who explained that the absence of the calf stimulus could be responsible of this response. Nevertheless, in this work, oxytocine was used in the MM method to promote the udder stimulation and milk release. The higher values of SE observed in the MY estimated by WSW method in this experiment, explain higher variability of this methodology to estimate MY. As reported by Espasandin et al. (2001), the differences in calves' weights before and after suckling may not be due only to milk consumption. Urine and feces losses in calves influence MY estimations. In this work, urine and faecal losses were not measured but estimated according to the observations of occurrence of these events. Probably these losses were overestimated by visual appreciations, being a possible reason to explain the higher MY in WSW method.

The non-linear models proposed by Jenkins and Ferrel (1984), and Wood (1967) showed different adjustments, being the AICC and BIC criteria lower in the Wood (higher adjustement) than in the JF curves. The adjusted lactation curves had similar tendencies to those observed in dairy cattle, with declines on milk production after an initial peak in the beginning of the lactation period (Notter, Cundiff, Smith, Laster, \& Gregory, 1978; Mondragón et al., 1983). The fitted W model for these primiparous cows showed values of 5.4, 0.19 and 0.18 for $\mathrm{a}, \mathrm{b}$ and $\mathrm{c}$ coefficients, respectively. In the peak, the milk production was in average $5.23 \mathrm{~kg} /$ day, being reached at 33.9 post-partum days. However, these values probably do not represent the potential milk production of beef cattle in grazing conditions of Uruguay. According to Clutter et al. (1987) the milk production in beef and dairy cows is affected by age of the cow, with heifers showing lower productions than multiparous cows. Drewry, Brown, and Honea (1959) observed daily milk productions up to $7 \mathrm{~kg}$ in Angus pure breed, and Lalman, Williams, Hess, Thomas, and Keisler (2009) observed daily productions of 6.5, 6.3 and $5.6 \mathrm{~kg}$ at 30,60 and 90 postpartum days in pure and crossbred Angus cows.

Also, the nutritional conditions affected the milk production in beef cows. Results published by Espasandin and Alencar (2003) in grazing systems of Brazil showed that milk yield peak was attained in the first week after calving, in Nellore cattle (with $7 \mathrm{~kg}$ /day) estimated by WSW method. In this work, the milk yield at peak was 5.3 $\mathrm{kg} /$ day and was attained at 32 post-partum days. These values are lower than those estimated by Jenkins and Ferrel (1992) where Angus and Hereford cows reached peaks at 9 and $8.5 \mathrm{~kg} /$ day. However, these authors measured in multiparous cows feed with higher levels of dietary energy. Age and breed dam are reported as most important factors determining milk yield in beef cattle (Melton Riggs, Nelson, \& Cartwright, 1967). In beef breeds, higher milk productions were observed from the second to the third calving (Mondragón et al., 1983). Using the WSW method in grazing conditions of Uruguay, previous researches found MY of 3.5 to 4.5/day in multiparous Hereford cattle (Franco, Echenagusía, Nuñez, Pereyra, \& Riani, 2002). Also, Quintans et al. (2010) used MM method and founded that milk production of backcrossed Hereford-Angus heifers was affected by body condition score. The observed averages were 4.1 and $3.6 \mathrm{~kg}$ /day in beef cows with medium and low body conditions scores, respectively.

The lack of breed effect observed in this experiment is not in agreement with published by Jenkins and Ferrel (1992, 1994). They found significant differences between breeds and crossbreed cows. In most cases, Angus showed higher milk productions than other British and Continental breeds (Miller et al., 1999). Jenkins et al. (1992) observed occurrences of lactation peaks early in Hereford than in Angus cows, whereas in the crosses, the peak appeared after the pure breeds. It is important to emphasize in this experiment the lower number of cows used for each genotype as well as the variability of the daily milk yield in grazing conditions.

The observed best adjustment in a non-linear model in this study are in agreement with observed by Espasandin and Alencar (2003) working with Nellore and Canchimbeef cattle in grazing systems of Brazil. Nevertheless, to observe higher adjustment in the JF model, the $\mathrm{W}$ curve is the best model used to describe the lactation of grazing beef heifers based on AICC and BIC criterias. Also, it is important to find an appropriate model to adjust milk yield in beef cows, since this trait is now included to estimate genetic values for maintenance requirements (Evans, 2001).

The energy content of milk (MeMY) varied significantly with the month of lactation while the cow's breed showed a statistical trend to be significant. The calf live weight varied inversely and is negatively correlated. The energy available to calves is higher in the beginning of the lactation period. Also, calf's requirements are proportional to their live weight (Neville et al., 1962). Thus, in the beginning of the lactation period, the energy 
available to the calf belongs from the dam. In grazing systems, as milk production of dam decreases, the grazing time of calf increases proportionally.

The tendencies observed in milk components are similar to the reported for beef cows (Mondragón et al., 1986) with higher percentages in protein and fat in the beginning and the end of lactation, and with decrease in lactose percentage along lactation period.

Similar to reported by Melton et al. (1967), Angus, Hereford and Charolais beef breeds showed no significant differences in solids, with values of $2.7 \%$ and $6.3 \%$ for fat and protein, respectively. Jenkins et al. (1992) reported 3.59\%, 3.38\% and 4.95\% for fat, protein and lactose, respectively in Angus beef breed. Also, there were no significant differences observed between F1 Angus x Hereford or Hereford x Angus breeds.

The differences in calves' weights are due to the different genetic effects such as individual and maternal heterosis and maternal breed effects (Dickerson, 1969). The phenotype of backcrossed calves from F1 dams is explained by individual and maternal heterosis as well as individual and maternal genetic direct effect of each breed (AA and $\mathrm{HH})$. On the other hand, $\mathrm{HH}$ calves phenotypes uniquely depend on the genetic individual and maternal Hereford effect. In spite of AA calves having the same effects, the higher weights in Angus calves was due to the great maternal ability of Angus dams. The weight and tendencies observed are similar to those published in grazing conditions of Uruguay (Espasandin et al., 2010) and Argentina (Melucci, Nicolini, Mezzadra, Miquel, Molinuevo, \& Villarreal, 1993).

Although the correlation coefficients between fitted (Wood) and originals (WSW and MM) milk productions and live weight of the calves was moderate and significant. The inclusion of milk yield (fitted and original WSW and $\mathrm{MM}$ ) as a covariate in the model was not significant. Maybe, this relationship can be described by a non-linear model.

Additionally, the correlation coefficients between milk production and calves live weight varied with the milking method. The milk production obtained by MM was strongly correlated with live than WSW milk. May these tendencies are explained by previously mentioned errors in WSW method.

In this experiment, it was possible to characterize the lactancies of pure and crossbred beef cows in grazing conditions of Uruguay, and quantify some relationships between calf performance and milk retained energy over the lactation period.

\section{Conclusions}

The estimations of milk yield in beef cattle were affected by extraction method.

The Wood model show greater adjustment to describe lactation curve in primiparous beef cows compared to linear models and non-linear J\&F model.

In the context of this experiment, the breed effect of the cow did not affect the milk yield, but affected the ReMY available to the calves.

\section{References}

Alencar, M. M., Cruz, G. M., da Tullio, R. R., \& Corrêa, L. A. (1995). Características da amamentação de bezerros da raça Canchim e cruzados Canchim x Nelore. Rev. Bras. Zootecn. Braz. J. Anim. Sci., 24, 706-714.

Alencar, M. M., Ruzza, F. J., \& Porto, E. J. S. (1988). Desempenho produtivo de fêmeas das raças Canchim e Nelore. III. produção de leite. Rev. Bras. Zootecn. Braz. J. Anim. Sci., 17, 317-328.

AOAC. (2012). In G. W. Latimer (Ed.), Official Methods of Analysis of AOAC International (19th ed., p. 17). Maryland, USA: AOAC International.

Arbelaez, M. B., Salazar, O. A., \& Vargas, J. A. M. (2007). ANOVA's method used to develop the study of repeatability and reproducibility inside of measure system. Scientia e Technica, 37, 533-537.

Barrentine, L. (1991). Concepts for $r \& R$ Studies. Milwaukee: ASQC Quality Press.

Dawson, W. M., Cook, A. C., \& Knapp, B. J. (1960). Milk production of beef Shorthorn cows. J. Anim. Sci., 19, 502-507.

Day, M. L., Imakawa, K., Clutter, A. C., Wolfe, P. L., Zalesky, D. D., Nielsen, M. K., \& Kinder, J. E. (1987). Suckling behavior of calves with dams varying in milk production. J. Anim. Sci., 65, 207-1212.

Dickerson, G. E. (1969). Experimental approaches in utilizing breed resources. Animal Breeding Abstract, 37, 191-202. 
Drewry, K. J., Brown, C. J., \& Honea, R. S. (1959). Relationship among factors associated with mothering ability in beef cattle. J. An. Sci., 18, 938-946.

Espasandin, A. C., \& Alencar, M. (2003). Modeling milk yield in Canchim and Nellore cows. Proceedings Contributed Papers IX World Conference on Animal Production - XVIII Reunião da Associação Latinoamericana de Produção Animal.

Espasandin, A. C., Ciria, M., Franco, J., Pereyra, F., \& Gimeno, D. (2010). Heterosis and productive and reproductive performance in Angus, Hereford and F1 reciprocal crossed cows on grazing systems of Uruguay. XXVI World Buiatrics Congress, Santiago de Chile.

Espasandin, A. C., Packer, I. U., \& Alencar, M. M. (2001). Produção de leite e comportamento de amamentação em cinco sistemas de produção em gado de corte. Rev. Bras. Zootecn. Braz. J. Anim. Sci., 30, 702-708. http://dx.doi.org/10.1590/S1516-35982001000300014

Evans, J. L. (2001). Genetic prediction of mature weight and mature cow maintenance energy requirements in Red Angus cattle (PhD Diss. Colorado State Univ., Fort Collins).

Fiss, C. F., \& Wilton, J. W. (1992). Contribution of Breed, Cow Weight, and Milk Yield to the traits of Heifers and Cows in Four Beef Breeding Systems. J. Anim. Sci., 70, 3686-3696.

Franco, J., Echenagusía, M., Nuñez, A., Pereyra, A., \& Riani, V. (2002). Destete temporario en vacas Hereford bajo pastoreo de campo natural. II. Producción de leche y peso de los terneros al destete. Xxx Jornadas Uruguayas De Buiatría, Paysandú, 2002 Editorial: Centro Médico Veterinario De Paysandú, Paysandú.

Gagliostro, G. A., Vidaurreta, L. I., Schroeder, G. F., Rodriguez, A., \& Gatti, P. (2002). Incrementando los valores basales de ácido linoleico conjugado (CLA) en la grasa butirosa de vacas lecheras en condiciones de pastoreo. Rev. Arg. Prod. Anim., 22(Suppl. 1), 59-60.

Gaskins, C. T., \& Anderson, D. C. (1980). Comparison of Lactation Curves in Angus-Hereford, Jersey-Angus and Simmental-Angus Cows. J. Anim. Sci., 50, 828-832.

Jenkins, T. G., \& Ferrell, C. L. (1984). A note on lactation curves of crossbred cows. Anim. Prod. Sci., 39, 479-482. http://dx.doi.org/10.1017/S0003356100032232

Jenkins, T. G., \& Ferrell, C. L. (1992). Lactation characteristics of nine breeds of cattle fed varying quantities of dietary energy. J. Anim. Sci., 70, 1652-1660.

Jenkins, T. G., Ferrell, C. L., \& Cundiff, L. V. (1986). Relationship of components of the body among mahue cows as related to size, lactation potential and possible effects on productivity. Anim. Prod., 43, 245-248. http://dx.doi.org/10.1017/S0003356100002427

Jenkins, T., \& Ferrell, C. (1994). Productivity though weaning of nine breed of cattle under varying feed availabilities: I. Initial Evaluation. J. Anim. Sci., 72, 2787-2797.

Lalman, D. L., Williams, J. E., Hess, B. W., Thomas, M. G., \& Keisler, D. H. (2000). Effect of dietary energy on milk production and metabolic hormones in thin, primiparous beef heifers. J. An. Sci., 78, 530-538.

Melton, A. A., Riggs, J. K., Nelson, L. A., \& Cartwright, T. C. (1967). Milk production, composition and calf gains of Angus, Charolais and Hereford cows. J. An. Sci., 26, 804-809.

Melucci, L., Nicolini, J., Mezzadra, C., Miquel, M. C., Molinuevo, H., \& Villarreal, E. (1993). Productividad hasta el destete en sistemas alternativos de cruzamientos en bovinos para carne. DIALOGOS IICA/PROCISUR, XXXV, 269-276.

Mondragón, I. Wilton, J. W., Allen, O. B., \& Song, H. (1983). Stage of Lactation Effects, Repeteabilities and Influences on Weaning Weights of Yield and Composition of Milk in Beef Cattle. Canadian J. Anim. Sci., 63, 751-761. http://dx.doi.org/10.4141/cjas83-090

Montaño-Bermudez, M., Nielsen, M. K., \& Deustcher, G. H. (1990). Energy requirements for maintenance of crossbred beef cattle with different genetic potential for milk. J. Anim. Sci., 68, 2279-2288.

Neville, E. W. Jr. (1962). Influence of Dam's Milk Production and other Factors on 120- and 240-Day Weight of Hereford Calves. J. Anim. Sci., 21, 315-320.

Notter, D. R., Cundiff, L. V., Smith, G. M., Laster, D. B., \& Gregory, K. E. (1978). Characterization of Biological Types of Cattle. VII. Milk Production in Young Cows and Transmitted and Maternal Effects on Preweaning Growth of Progeny. J. An. Sci., 46, 908-921.

Pallares, O. R., Berretta, E. J., \& Maraschin, G. E. (2005). The South American Campos ecosystem. In J. Suttie, 
S. G. Reynolds, \& C. Batello (Eds.), Grasslands of the world (pp. 171-219). FAO.

Quintans, G., Banchero, G., Carriquiry, M., López-Mazz, C., \& Baldi, F. (2010). Effect of body condition and suckling restriction with and without presence of the calf on cow and calf performance. Anim. Prod. Sci., 50, 931-938. http://dx.doi.org/10.1071/AN10021

SAS. (2009). Statistical Analysis System, Inc. Institute, SAS.

Strabel, T., \& Misztal, I. (1999). Genetic Parameters for First and Second Lactation Milk Yields of Polish Black and White Cattle. J. Dairy Sci., 82, 2805-2810. http://dx.doi.org/10.3168/jds.S0022-0302(99)75538-4

Totusek, R., Arnett, D. W., Holland, G. L., \& Whiteman, J. V. (1973). Relation of Estimation Method, Sampling Interval and Milk Composition to Milk Yield of Beef Cows and Calf Gain. J. Anim. Sci., 37(1), 153-158.

Tyrrell, H. F., \& Reid, J. T. (1965). Prediction of the energy value of cow's milk. J. Dairy Sci., 48, 1215-1223. http://dx.doi.org/10.3168/jds.S0022-0302(65)88430-2

Ünal, N., Atasoy, F., Akçapinar, H., Koçak, S., Yakan, A., Erol, H., \& Uğurlu, M. (2007). Milk yield measured by oxytocin plus hand milking and weigh-suckle-weigh methods in ewes originating from local crossbred in Turkey. Revue Méd.Vét., 158, 320-325.

Williams, J. H., Anderson, D. C., \& Kress, D. D. (1979). Milk production in Hereford cattle, I. Effects of separation interval on weigh-suckle-weigh milk production estimates. J. An. Sci., 49, 1438-1442

Wood, P. D. P. (1967). Algebraic model of the lactation model in cattle. Nature, 216, 164-165. http://dx.doi.org/10.1038/216164a0

Yokoi, N., Moriya, K., \& Sasaki, Y. (1997). A measure for predicting genetic merit for milking and nursing ability in beef cattle. Anim. Sci., 65, 39-43. http://dx.doi.org/10.1017/S1357729800016271

\section{Copyrights}

Copyright for this article is retained by the author(s), with first publication rights granted to the journal.

This is an open-access article distributed under the terms and conditions of the Creative Commons Attribution license (http://creativecommons.org/licenses/by/3.0/). 